\title{
PENENTUAN NILAI SPF EKSTRAK ETIL ASETAT DAUN MANGGA GEDONG MENGGUNAKAN SPEKTROFOTOMETRI UV - VIS
}

\author{
Nia Lisnawati ${ }^{1}$, M. Fathan N.U ${ }^{2}$ Dwi Nurlitasari ${ }^{3}$ \\ ${ }^{1,2,3}$ Akademi Farmasi IKIFA \\ Email Korespondensi : aqilputranida@gmail.com
}

\begin{abstract}
ABSTRAK
Senyawa fenolik khususnya golongan flavonoid mempunyai potensi sebagai tabir surya karena adanya gugus kromofor (ikatan rangkap tunggal terkonjugasi) yang mampu menyerap sinar UV baik UV A maupun UV B sehingga mengurangi intensitasnya pada kulit. Flavonoid memiliki tiga sifat fotoprotektor yaitu penyerapan UV, sifat antioksidan, dan memodulasi beberapa jalur pensinyalan DNA. Tujuan dari penelitian ini adalah untuk mengetahui nilai SPF (Sun Protection Factor) ekstrak etil asetat daun mangga gedong menggunakan spektrofotometri UV-Vis. Simplisia daun mangga gedong diekstrak menggunakan pelarut etil asetat dengan cara refluks. Ekstrak daun mangga gedong diidentifikasi senyawa flavonoid menggunakan $\mathrm{NaOH} 10 \%$ dan

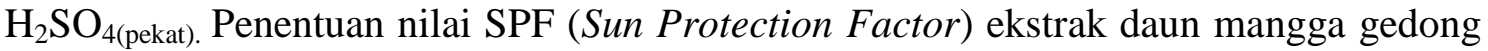
menggunakan metode spektrofotometri UV-Vis. Konsentrasi ekstrak etil asetat daun mangga gedong yang digunakan yaitu 120 ppm, 240 ppm dan 360 ppm. Nilai SPF (Sun Protection Factor) dianalisis menggunakan metode Mansur. Hasil identifikasi senyawa flavonoid menunjukkan bahwa ekstrak etil asetat daun mangga gedong positif mengandung flavonoid, sedangkan hasil nilai SPF (Sun Protection Factor) ekstrak etil asetat daun mangga gedong berturut-turut 5,556; 16,675 dan 22,243. Nilai SPF (Sun Protection Factor) ekstrak etil asetat daun mangga gedong 5,556 termasuk tipe proteksi sedang, 16,675 dan 22,243 termasuk tipe proteksi ultra apabila diuji menggunakan spektrofotometri UV-Vis dengan metode Mansur.
\end{abstract}

Kata kunci: SPF, Ekstrak, Etil Asetat, Daun Mangga Gedong, Spektrofotometri UVVis. 


\section{ABSTRACT}

Phenolic compounds especially flavonoid groups have the potential as a sunscreen because of the chromophore group (single conjugated double bond) capable of absorbing $U V$ light both $U V A$ and $U V B$, thus reducing the intensity of the skin. Flavonoids have three properties of photoprotektor that is UV absorption, antioxidant properties, and modulate some DNA signaling pathways. The purpose of this research is to know the value of SPF (Sun Protection Factor) of ethyl acetate extract of mango gedong leaves using UV-Vis spectrophotometry. Simplicia gedong mango leaves were extracted using ethyl acetate solvent by reflux. Gedong mango leaf extract identified flavonoid compound using $10 \% \mathrm{NaOH}$ and $\mathrm{H} 2 \mathrm{SO} 4$ (concentrated). Determination of SPF (Sun Protection Factor) value of med gedong leaf extract using UV-Vis spectrophotometry method. The concentration of ethyl acetate extract of mango gedong leaves used was 120 ppm, 240 ppm and 360 ppm. The SPF (Sun Protection Factor) values were analyzed using Mansur method. The result of identification of flavonoid compound showed that the extract of ethyl acetate of mango gedong leaves positively contain flavonoids, while the result of SPF (Sun Protection Factor) extract of ethyl acetate of mango gedong leaves was 5,556; 16,675 and 22,243. The SPF (Sun Protection Factor) extract of 5,556 muddy ethyl acetate leaves including moderate protection type, 16,675 and 22,243 including ultra-protection type when tested using UV-Vis spectrophotometry by Mansur method.

Keywords: SPF, Extract, Ethyl Acetate, Gedong Mango Leaf, UV-Vis Spectrophotometry

\section{PENDAHULUAN}

Paparan sinar matahari yang berlebih dan berlangsung lama dapat menyebabkan jaringan epidermis kulit tidak cukup mampu melawan efek negatif yang ditimbulkan seperti kelainan kulit mulai dari dermatitis ringan sampai kanker kulit (Marliani, 2015). Efek buruk dari radiasi sinar matahari pada kulit manusia dapat menyebabkan sunburn, pigmentasi kulit, penuaan dini, dan kanker kulit pada manusia (Zulkarnain, 2013). Salah satu cara yang dilakukan untuk mengurangi dampak negatif dari sinar matahari yaitu dengan menggunakan tabir surya (Marliani, 2015).
Tabir surya dapat menyerap sedikitnya $85 \%$ sinar matahari pada panjang gelombang 290-320 nm untuk UV B tetapi dapat meneruskan sinar pada panjang gelombang lebih dari 320400 nm untuk UV A (Marliani, 2015). Tabir surya dapat melindungi kulit dengan cara menyebarkan sinar matahari atau menyerap energi radiasi sinar matahari yang mengenai kulit (Zulkarnain, 2015). Preparat tabir surya dianjurkan penggunaannya untuk mencegah dan meminimalkan efek sinar UV yang berbahaya terhadap kulit (Susanti, 2012)

Senyawa-senyawa fenolik dapat berperan sebagai bahan aktif tabir surya (Lumempouw, 2012). Senyawa fenolik 
memiliki ikatan yang saling berkonjugasi dalam inti benzen dimana saat terpapar sinar UV akan terjadi resonansi dengan transfer elektron. Adanya kesamaan sistem konjugasi pada senyawa fenolik dan senyawa kimia yang biasanya terkandung di dalam tabir surya menyebabkan senyawa ini berpotensi sebagai photoprotective (Prasiddha, 2016). Senyawa fenolik khususnya golongan flavonoid mempunyai potensi sebagai tabir surya karena adanya gugus kromofor (ikatan rangkap tunggal terkonjugasi) yang mampu menyerap sinar UV baik UV A maupun UV $B$ sehingga mengurangi intensitasnya pada kulit (Zulkarnain, 2013). Flavonoid memiliki tiga sifat fotoprotektor yaitu penyerapan UV, sifat antioksidan, dan memodulasi beberapa jalur pensinyalan DNA (Purwaningsih, 2015).

Potensi tabir surya dapat dinyatakan dengan Sun Protection Factor (SPF) (Zulkarnain,2013). Nilai SPF diukur sebagai kemampuan atau efektivitas suatu bahan tabir surya. Nilai SPF menunjukkan kemampuan produk tabir surya untuk mengurangi eritema yang diakibatkan karena radiasi sinar UV (Lolo, 2017). Nilai Sun Protection Factor (SPF) menggambarkan kemampuan tabir surya dalam melindungi kulit dari eritema. SPF diperuntukkan sebagai perlindungan UV $\mathrm{B}$ dan tidak secara khusus diperuntukkan untuk melawan UV A dan UV C (Purwaningsih, 2015).

Penelitian sebelumnya telah dilakukan penapisan fitokimia ekstrak etil asetat daun mangga gedong. Hasil penapisan fitokimia ekstrak etil asetat daun mangga gedong menunjukkan bahwa ekstrak etil asetat daun mangga gedong mengandung flavonoid (Rahmiyani, 2016). Senyawa aktif yang berpotensi sebagai tabir surya yaitu flavonoid karena kandungan flavonoid yang tinggi mempunyai nilai SPF tertinggi (Pontoan, 2016). Hasil dari penelitian ekstrak yang mengandung senyawa flavonoid mempunyai nilai SPF (Alhabsyi, 2014).

Metode untuk penentuan nilai SPF dapat dilakukan dengan metode spektrofotometri dengan pengenceran kalkulasi nilai SPF menggunakan metode Mansur. Metode ini terbukti akurat dan mudah untuk dilakukan. Metode spektrofotometri UV simpel, cepat, dan membutuhkan biaya yang sedikit (Yulianti, 2015)

Saat ini belum ada penelitian nilai SPF (Sun Protection Factor) ekstrak etil asetat daun mangga gedong menggunakan spektrofotometri UV-Vis. Adanya kandungan flavonoid dalam ekstrak etil asetat daun mangga gedong berpotensi mempunyai nilai SPF (Sun Protection Factor), maka perlu dilakukan penelitian mengenai penentuan nilai SPF (Sun Protection Factor) ekstrak etil asetat daun mangga gedong menggunakan spektrofotometri UV-Vis.

\section{METODE PENELITIAN \\ Pembuatan Simplisia Daun Mangga Gedong}

Daun mangga gedong disortasi basah, ditimbang sebanyak $1 \mathrm{~kg}$, dicuci dengan air mengalir didiamkan selama semalam, daun mangga gedong di rajang atau dipotong kecil, dikeringkan dengan cara diangin-anginkan dalam ruangan 
tidak terkena sinar matahari secara langsung (Pamungkas, 2016). Tanda simplisia sudah kering adalah mudah meremah bila diremas atau mudah patah. Pengeringan daun mangga gedong sampai kadar air <10\%. Setelah simplisia kering selanjutnya dilakukan sortasi kering ( Emilan, 2011).

\section{Pembuatan Ekstrak Etil Asetat Daun Mangga Gedong}

Simplisia daun mangga gedong dihaluskan dengan menggunakan blender kemudian diayak dengan ayakan 40 mesh (Sembiring, 2006). Timbang sebanyak 50 gram serbuk daun mangga gedong, masukkan ke dalam labu alas bulat $500 \mathrm{~mL}$, tambahkan etil asetat p.a (pro analis) sebanyak $250 \mathrm{~mL}$ (Alhabsyi, 2014). Direfluks selama 30 menit, diangkat dan disaring, filtrat disisihkan, lalu ampas direfluks kembali sebanyak dua kali (Mujahid, 2011). Filtrat 1, 2, dan 3 digabung menjadi satu, pelarut diuapkan menggunakan waterbath pada suhu $60^{\circ} \mathrm{C}$. Rendemen yang diperoleh ditimbang dan dicatat (Hariati, 2014).

Rendemen:

Bobot ekstrak didapat x 100\%

Bobot simpisia

\section{Identifikasi Senyawa Flavonoid}

a. Identifikasi test dengan $\mathrm{NaOH} 10 \%$

Test dengan $\mathrm{NaOH} 10 \%$ dengan cara memasukkan dua tetes sampel dalam tabung reaksi, ditambahkan dengan 2-4 tetes larutan $\mathrm{NaOH} 10 \%$, perubahan warna diamati hingga menjadi warna kuning sampai kuning kecoklatan. Hal ini dikarenakan flavonoid termasuk senyawa fenol sehingga apabila direaksikan dengan basa akan terbentuk warna yang disebabkan terjadinya sistem konjugasi dari gugus aromatik (Kusnadi, 2017).

b. Uji warna test dengan $\mathrm{H}_{2} \mathrm{SO}_{4}$ (pekat)

Test dengan $\mathrm{H}_{2} \mathrm{SO}_{4}$ (pekat) dengan cara memasukkan 4 tetes sampel dalam tabung reaksi tambahkan 2-4 tetes larutan $\mathrm{H}_{2} \mathrm{SO}_{4}$ (pekat). Perubahan warna yang terjadi diamati menjadi merah bata sampai coklat kehitaman hal ini disebabkan karena flavonoid apabila direaksikan dengan asam akan terbentuk warna yang disebabkan terjadinya sistem konjugasi dari gugus khalkon (Kusnadi, 2017).

\section{Penentuan Nilai SPF (Sun Protection Factor)}

Ekstrak etil asetat daun mangga gedong diambil sebanyak 1,2 mg; 2,4 mg; dan 3,6 mg kemudian diencerkan dengan etanol $70 \%$ hingga $10 \mathrm{~mL}(120$ ppm, 240 ppm, dan 360 ppm). Spektrofotometer UV-Vis dikalibrasi terlebih dahulu dengan menggunakan etanol $70 \%$ dan etanol $70 \%$ dimasukkan ke dalam kuvet. Dibuat kurva serapan uji dalam kuvet dengan panjang gelombang antara 290-320 nm, etanol 70\% digunakan sebagai blanko. Kemudian tetapkan serapan dengan interval $5 \mathrm{~nm}$. Hasil absorbansi masing-masing konsentrasi dicatat dan kemudian nilai SPFnya dihitung dengan menggunakan metode Mansur (Yulianti, 2015). Masing-masing sampel dilakukan tiga kali penentuan tiap poinnya (Susanti, 2012). Nilai SPF dianalisis menggunakan metode Mansur:

$\mathrm{SPF}=\mathrm{CF} \times \sum_{290}{ }^{320} \mathrm{Abs}(\lambda) \mathrm{xEE}(\lambda) \mathrm{x} \mathrm{I}(\lambda)$

Keterangan :

EE : Spektrum efek eritemal

I : Intensitas spektrum sinar 
Abs : Serapan produk tabir surya

CF : Faktor koreksi $(=10)$

Berdasarkan penelitian (Susanti, 2012) nilai EE adalah konstan dan ditunjukkan pada Tabel 1. Berikut:

Tabel 1. Nilai EE $x$ I Pada Panjang Gelombang 290-320 nm

\begin{tabular}{cc}
\hline $\begin{array}{c}\text { Panjang gelombang } \\
(\mathbf{n m})\end{array}$ & EE x I \\
\hline $\mathbf{2 9 0}$ & 0,0150 \\
$\mathbf{2 9 5}$ & 0,0817 \\
$\mathbf{3 0 0}$ & 0,2874 \\
$\mathbf{3 0 5}$ & 0,3278 \\
$\mathbf{3 1 0}$ & 0,1864 \\
$\mathbf{3 1 5}$ & 0,0839 \\
$\mathbf{3 2 0}$ & 0,0180 \\
Total & 1 \\
\hline
\end{tabular}

\section{HASIL DAN PEMBAHASAN}

\section{Hasil Ekstrak Etil Asetat Daun Mangga Gedong}

Berdasarkan Tabel 2 dan Gambar 4.1 menunjukkan bahwa volume filtrat ekstrak etil asetat daun mangga gedong berbeda-beda. Pada ekstraksi yang pertama menghasilkan volume filtrat yang paling sedikit sedangkan pada ekstraksi yang ke tiga menghasilkan volume filtrat yang paling banyak. Dilihat dari volume filtrat ekstrak etil asetat daun mangga gedong dapat diketahui bahwa semakin banyak dilakukan pengulangan ekstraksi pada serbuk simplisia yang sama maka volume filtrat yang dihasilkan semakin banyak. Hal ini disebabkan oleh berkurangnya senyawa yang dapat ditarik oleh pelarut etil asetat. Pada ekstraksi pertama volume filtrat dihasilkan jauh lebih sedikit bila dibandingkan dengan ekstraksi yang ke dua dan ke tiga dikarenakan oleh penguapan pelarut dan tingkat penyerapan oleh serbuk simplisia.

Berdasarkan Tabel 2 menunjukkan bahwa semakin sedikit volume filtrat ekstrak etil asetat daun mangga gedong maka warna filtrat ekstrak etil asetat daun mangga gedong sangat pekat, sedangkan semakin banyak volume filtrat ekatrak etil asetat daun mangga gedong maka warna filtrat ekstrak etil asetat daun mangga gedong semakin tidak pekat. Hal ini dapat dilihat pada volume filtrat ekstrak etil asetat daun mangga gedong $128 \mathrm{~mL}$ memiliki warna hijau kehitaman sangat pekat, volume filtrat ekstrak etil asetat daun mangga gedong $186 \mathrm{~mL}$ memiliki warna hijau kehitaman pekat, dan volume ekstrak etil asetat daun mangga gedong $200 \mathrm{~mL}$ memiliki warna hijau lumut. Warna filtrat dipengaruhi oleh tingkat penyerapan pelarut karena semakin banyak senyawa yang diikat warna filtrat semakin pekat dan semakin sedikit warna filtrat yang dihasilkan akan semakin tidak pekat.

Tabel 2. Hasil Volume Filtrat dan Warna Filtrat Ekstrak Etil Asetat Daun Mangga Gedong

\begin{tabular}{|c|c|c|}
\hline $\begin{array}{c}\text { Filtrat } \\
\text { ke- }\end{array}$ & $\begin{array}{c}\text { Volume } \\
\text { Filtrat }(\mathbf{m L}) \\
\end{array}$ & $\begin{array}{c}\text { Warna Filtrat } \\
\text { Ekstrak }\end{array}$ \\
\hline 1 & 128 & $\begin{array}{l}\text { Hijau kehitaman } \\
\text { sangat pekat }\end{array}$ \\
\hline 2 & 186 & $\begin{array}{l}\text { Hijau kehitaman } \\
\text { pekat }\end{array}$ \\
\hline 3 & 200 & Hijau lumut \\
\hline Total & 514 & \\
\hline
\end{tabular}

\section{Hasil Rendemen Ekstrak Etil Asetat} Daun Mangga Gedong

Tabel 3. Hasil Rendemen Ekstrak Etil Asetat Daun Mangga Gedong 


\begin{tabular}{ccc}
\hline $\begin{array}{c}\text { Bobot Simplisia } \\
\text { Daun Mangga } \\
\text { Gedong yang } \\
\text { Diekstrak } \\
\text { (gram) }\end{array}$ & $\begin{array}{c}\text { Bobot } \\
\text { Ekstrak } \\
\text { yang } \\
\text { Didapat } \\
\text { (gram) }\end{array}$ & $\begin{array}{c}\text { Rendemen } \\
(\boldsymbol{\%})\end{array}$ \\
\hline 50,0003 & 4,7694 & 9,5387 \\
\hline
\end{tabular}

Berdasarkan Tabel

3. menunjukkan bahwa rendemen ekstrak etil asetat daun mangga gedong sebanyak 9,5387\%. Hasil rendemen ini diperoleh dari semua jumlah filtrat ekstrak etil asetat daun mangga gedong pada ekstraksi pertama, ke dua, dan ke tiga yang diuapkan hingga menjadi ekstrak kental. Pengupan semua jumlah filtrat ekstrak etil asetat daun mangga gedong membutuhkan waktu selama 15 jam 15 menit menggunakan waterbath pada suhu $60^{\circ} \mathrm{C}$. Penguapan dilakukan pada suhu $60^{\circ} \mathrm{C}$ karena proses pengupan dari ekstrak mempengaruhi hasil rendemen (Hariati, 2014).

\section{Hasil Pemeriksaan Secara Organoleptik Ekstrak Etil Asetat Daun Mangga Gedong}

Ekstrak etil asetat daun mangga gedong dilakukan pemeriksaan secara organoleptik. Pemeriksaan secara organoleptik meliputi bentuk, bau, dan warna ekstrak etil asetat daun mangga gedong. Organoleptik bertujuan sebagai pengenalan awal yang sederhana seobyektif mungkin menggunakan panca indra dengan mendeskripsikan bentuk, warna, dan bau. Berdasarkan Tabel 4 ekstrak etil asetat daun mangga gedong mempunyai bentuk kental, warna hijau kehitaman, dan bau khas.
Tabel 4. Hasil Pemeriksaan Secara Organoleptik Ekstrak Etil Asetat Daun Mangga Gedong

\begin{tabular}{cc}
\hline Pemerian & Hasil Ekstrak \\
Ekstrak Daun & Etil Asetat \\
Mangga & Daun Mangga \\
Gedong & Gedong \\
\hline Bentuk & Kental \\
Warna & Hijau Kehitaman \\
Bau & Khas \\
\hline
\end{tabular}

Identifikasi senyawa flavonoid dilakukan untuk mengetahui ekstrak etil asetat daun mangga gedong mengandung flavonoid atau tidak. Identifikasi senyawa flavonoid dilakukan dengan metode reaksi warna. Uji ini digunakan untuk membuktikan terjadinya reaksi kimia dengan mengamati ciri-ciri yang terjadi seperti adanya perubahan warna. Dalam uji reaksi warna yang dilakukan reaksi yang teramati adalah perubahan warna (Kusnadi, 2017)

Berdasarkan Tabel 5 menunjukkan ekstrak etil asetat daun mangga gedong mengandung flavonoid karena terjadi perubahan warna kuning setelah ditetesi $\mathrm{NaOH} 10 \%$. Uji identifikasi yang kedua terjadi perubahan warna coklat kehitaman setelah ditetesi $\mathrm{H}_{2} \mathrm{SO}_{4 \text { (pekat). }}$ Hal ini membuktikan bahwa ekstrak etil asetat daun mangga gedong mengandung senyawa flavonoid. Hasil ini sesuai dengan identifikasi flavonoid pada ekstrak etil asetat daun mangga gedong yang menyatakan bahwa ekstrak etil asetat daun mangga gedong mengandung senyawa kimia berupa flavonoid (Rahmiyani, 2016). 


\section{Hasil Identifikasi Senyawa Flavonoid}

Tabel 5. Hasil Identifikasi Senyawa Flavonoid Ekstrak Daun Mangga Gedong

\begin{tabular}{|c|c|c|c|c|}
\hline Pemeriksaan & Pereaksi & Percobaan & $\begin{array}{c}\text { Hasil } \\
\text { Pengujian }\end{array}$ & Indikator \\
\hline \multirow[t]{2}{*}{ Flavonoid } & $\mathrm{NaOH} 10 \%$ & $\begin{array}{lr}\text { Ekstrak } & \text { Etil } \\
\text { Asetat } & \text { Daun } \\
\text { Mangga } & \text { Gedong } \\
+\mathrm{NaOH} & 10 \%\end{array}$ & + & $\begin{array}{l}\text { Perubahan warna } \\
\text { kuning kecoklatan }\end{array}$ \\
\hline & $\mathrm{H}_{2} \mathrm{SO}_{4 \text { (pekat) }}$ & $\begin{array}{lr}\text { Ekstrak } & \text { Etil } \\
\text { Asetat } & \text { Daun } \\
\text { Mangga } & \text { Gedong } \\
+\mathrm{H}_{2} \mathrm{SO}_{4 \text { (pekat) }}\end{array}$ & + & $\begin{array}{l}\text { Perubahan warna } \\
\text { merah bata sampai } \\
\text { coklat kehitaman }\end{array}$ \\
\hline
\end{tabular}

Keterangan hasil pengujian : tidak ada flavonoid (-), ada flavonoid(+)

Hasil Penentuan Nilai SPF (Sun Protection Factor) EkstrakEtil Asetat Daun Mangga Gedong

Penilaian SPF menurut Food and

Drug Administration (FDA) tipe proteksi minimal mempunyai niali SPF 1-4, tipe proteksi sedang mempunyai nilai SPF 46 , tipe proteksi ekstra mempunyai nilai SPF 6-8, tipe proteksi maksimal mempunyai nilai SPF 8-15, dan tipe proteksi ultra mempunyai nilai SPF $>15$ (Prasiddha, 2016). Berdasarkan Tabel 6 menunjukkan bahwa ekstrak etil asetat daun mangga gedong dengan konsentrasi 120 ppm mempunyai nilai SPF (Sun Protection Factor) 5,556 termasuk tipe proteksi sedang apabila diukur menggunakan spektrofotometri UV-Vis dengan metode Mansur. Ekstrak etil asetat daun mangga gedong dengan konsentrasi 240 ppm mempunyai nilai (Sun Protection Factor) 16,675 termasuk tipe proteksi ultra apabila di ukur menggunakan spektrofotometri UV-Vis dengan metode Mansur. Ekstrak etil asetat daun mangga gedong dengan konsentrasi 360 ppm mempunyai nilai (Sun Protection Factor) 22,243 termasuk tipe proteksi ultra apabila diukur menggunakan spektrofotometri UV-Vis dengan metode Mansur.

Berdasarkan Tabel 6 dmenunjukkan bahwa perbandingan konsentrasi berbanding lurus (Yulianti, 2015). Hal ini karena semakin tinggi konsentrasi ekstrak etil asetat daun mangga gedong maka nilai SPF (Sun Protection Factor) ekstrak etil asetat daun mangga gedong semakin tinggi, sedangkan semakin rendah konsentrasi ekstrak etil asetat daun mangga gedong maka nilai SPF (Sun Protection Factor) ekstrak etil asetat daun mangga gedong semakin rendah. Jadi konsentrasi ekstrak etil asetat daun mangga gedong mempengaruhi nilai SPF (Sun Protection Factor).

Hasil dari penelitian ini, ekstrak etil asetat daun mangga gedong mengandung flavonoid dan mempunyai nilai SPF (Sun Protection Factor). Flavonoid diduga komponen yang dapat menangkal radikal induksi ultraviolet (UV), flavonoid juga diduga memberikan efek perlindungan terhadap radiasi dengan penyerap UV 
(Purwaningsih, 2015). Flavonoid memiliki potensi tabir surya karena adanya gugus kromofor. Gugus kromofor tersebut merupakan sistem aromatik terkonjugasi yang menyebabkan untuk menyerap kuat sinar UV pada kisaran gelombang UV baik
UV A maupun UV B.(2) Flavonoid memiliki tiga sifat fotoprotektor yaitu penyerapan UV, sifat antioksidan, dan beberapa jalur pensinyalan DNA (Purwaningsih, 2015).

Tabel 6. Nilai SPF (Sun Protection Factor) Ekstrak Etil Asetat Daun Mangga Gedong

\begin{tabular}{ccl}
\hline Konsentrasi (ppm) & $\begin{array}{c}\text { Nilai SPF (Sun Protection } \\
\text { Factor) Ekstrak Etil Asetat } \\
\text { Daun Mangga Gedong }\end{array}$ & Tipe Proteksi \\
\hline $\mathbf{1 2 0}$ & 5,556 & Proteksi sedang \\
$\mathbf{2 4 0}$ & 16,675 & Proteksi ultra \\
$\mathbf{3 6 0}$ & 22,243 & Proteksi ultra \\
\hline
\end{tabular}

\section{SIMPULAN}

Ekstrak etil asetat daun mangga gedong konsentrasi 120 ppm memiliki nilai SPF (Sun Protection Factor) 5,556 termasuk tipe proteksi sedang, konsentrasi 240 ppm memiliki nilai SPF (Sun Protection Factor) 16,675 termasuk tipe proteksi ultra, dan konsentrasi 360 ppm memiliki nilai SPF (Sun Protection Factor) 22,243 termasuk tipe proteksi ultra apabila diuji menggunakan spektrofotometri UV-Vis dengan metode Mansur.

\section{UCAPAN TERIMAKASIH}

Terimakasih kepada Akademi Farmasi IKIFA atas semua fasilitas laboratorium yang memudahkan peneliti dalam pengambilan data penelitian.

\section{DAFTAR PUSTAKA}

Alhabsyi DF, Edi S, Defny SW. Aktivitas antioksidan dan tabir surya pada ekstrak kulit buah pisang Groho (Musa acuminate L.). Pharmacon Jurnal Ilmiah Farmasi. 2014; 3(2): h 107-14.

Emilan T, Ashfar K, Budi U, Liliek ND, Andhien M. Konsep herbal Indonesia: pemastian mutu produk herbal. Depok: Fakultas Matematika Dan Ilmu Pengetahuan Alam Departemen Farmasi Program Studi Magister Ilmu Herbal Depok; 2011, h 7-11.

Hariati S. Analisis kromatographic ekstrak dan produk temulawak (Curcuma xantorrhiza Roxb) menggunakan GC-MS (Gas Chromatography-Mass

Spectrometry). (Skripsi). Surakarta: Fakultas Farmasi Universitas Muhammadiyah Surakarta; 2014, h 1-14.

Kusnadi K, Egie TD. Isolasi dan identifikasi senyawa flavonoid pada ekstrak daun seledri (Apium graveolens L.) dengan metode refluks. Pancasakti Scienci 
Education Journal. 2017; 2(1): h 56-67.

Lolo WA, Sri S, Hosea JE. Penentuan nilai Sun Protection Factor (SPF) herba krokot (Portulacaoleracea L.). Jurnal of Pharmaceutical Science and Clinical Research. 2017;02: h 1-5.

Lumempouw LI, Edi S, Jessy JEP. Aktivitas anti UV B ekstrak fenolik dari tongkol jagung (Zea mays L.). JURNAL MIPA UNSRAT. 2012; 1(1): h 1-4.

Marliani L, Rosyta V, Asep R. Aktivitas antioksidan dan tabir surya pada ekstrak kulit buah papaya (Carica papaya L.). Dalam : Prosiding Seminar Nasional Penelitian dan PKM Kesehatan. Bandung: Sekolah Tinggi Farmasi Bandung; 2015, h 319-24.

Mujahid R, Awal PKD, Nita S. Maserasi sebagai alternatif ekstraksi pada penetapan kadar kurkuminoid simplisia temulawak (Curcuma xanthorriza Roxb). EPublikasi Fakultas Farmasi. 2011; h 18-23.

Pamungkas DK. Pengujian aktivitas antioksidan dan penetapan kadar fenol total kombinasi ekstrak methanol daun mangga gadung (Mangifera indica L. var. gadung) dan ekstrak etanol daun pandan wangi (Pandanus amaryllifolius Roxb.). (skripsi). Jember: Fakultas Farmasi Universitas Jember; 2016.

Pontoan J. Uji aktivitas antioksidan dan tabir surya dari ekstrak daun alpukat (Persea Americana M.). Indonesia Natural Research Pharmaceutical Journal Universitas
17 Agustus 1945 Jakarta. 2016; 1(1): h 55-66.

Prasiddha IJ, Rosalina AL, Teti Estiasih, Jaya MM. Potensi senyawa bioaktif rambut jagung (Zea mays L.) untuk tabir surya alami: kajian pustaka. Jurnal Pangan dan Argoindustri. 2016; 4(1): h 40-45.

Purwaningsih S, Ella S, Adnin MN. Efek fotoprotektif krim tabir surya dengan penambahan karaginan dan buah bakau hitam (Rhizopora mucronata Lamk.). Jurnal Ilmiah dan Teknologi Kelautan Tropis. 2015; 7(1): h 1-14.

Rahmiyani I, Lusi N. Aktivitas antioksidan ekstrak daun mangga Mangifera indica L. Var. Gedong menggunakan DPPH. Jurnal Kesehatan Bakti Tunas Husada. 2016; 16(1): h 17-23.

Sembiring BB, Ma'mun, Edi IG. Pengaruh kehalusan bahan dan lama ekstraksi terhadap mutu ekstrak temulawak (Curcuma xanthorriza Roxb). Bul. Littro. 2006; 17(2): h 53-58

Susanti M, Dachriyanus, Doni PP. Aktivitas perlindungan sinar UV kulit buah Garcinia mangostana Linn secara in vitro. Pharmacon. 2012; 13(2): h 61-64.

Yulianti E, Adeltrudis A, Alifia P. Penentuan nilai SPF ekstrak etanol $70 \%$ temu mangga (Curcuma mangga) secara in vitro menggunakan metode spektrofotometri. Majalah Kesehatan FKUB. 2015; 2(1): h 4150. 
Zulkarnain AK, Hidayatu HS. Stabilitas fisik dan aktivitas krim w/o ekstrak etanolik buah mahkota dewa (Phaleria macrocarph (Scheff.) Boerl,) sebagai tabir surya. Trad. Med. J. 2013; 18(2): h 109-17.
Zulkarnain AK, Wiweka AP. Uji SPF in vitro dan sifat fisik beberapa produk tabir surya yang beredar di pasaran. Makalah Farmasetik. 2015; 11(1): h 275-83. 